\title{
Empirical Identification of Determinants of Firm's Financial Performance: a Comparative Study on Textile and Food Sector of Pakistan
}

\author{
Waqas Tariq \\ Hailey College of Commerce, University of Punjab, Lahore, Pakistan \\ E-mail: tariq.waqas@ymail.com \\ Imran Ali \\ Hailey College of Commerce, University of Punjab, Lahore, Pakistan \\ E-mail: azan105@yahoo.com
}

Hafiz Muhammad Usman

Hailey College of Commerce, University of Punjab, Lahore, Pakistan

E-mail: Usmanlodhi_786@yahoo.com

Jawad Abbas

Hailey College of Commerce, University of Punjab, Lahore, Pakistan

E-mail: jawadbutt1988@yahoo.com

Zahid Bashir (Corresponding Author)

Faculty of Finance at School of Business, Economics \& Management Sciences

Imperial College of Business Studies Lahore, Pakistan

Tel: 92-323-849-8515 E-mail: zahid.bashir.332@gmail.com

Received: January 10, 2013 Accepted: February 2, 2013

doi:10.5296/ber.v3i1.3851 URL: http://dx.doi.org/10.5296/ber.v3i1.3851 


\section{Abstract}

The current research empirically identifies the factors significantly affecting the firm's performance in textile and food sector of Pakistan. The researcher used panel/longitudinal data set which are created with the help of State Bank of Pakistan's annual publication named as "Financial statement analysis of companies (non-financial) listed in KSE for the period 2005 to 2010 which is available at www.sbp.org.pk online. The researcher used one-way fixed effect model due to the presence of cross-sectional fixed effect in the regression results. The dependent variable was profitability as a measure of firm's financial performance while the independent variables were leverage, growth, firm's size, risk, tax, tangibility, liquidity and non-debt tax shield. The firm's performance in case of textile sector is significantly affected by Short term leverage, Size, risk, tax and non-debt tax shield while taking long term leverage as first independent variable, the leverage becomes insignificant along with tax factor. In food sector, Long term leverage, size, risk, tangibility and non-debt tax shield are the factors significantly affecting the firm's financial performance. The textile and food sector should consider the above said factors because these factors significantly increasing or decreasing firm's financial performance. The findings of the current research are limited and applicable to non-financial sector of Pakistan only. It is not applicable to financial sector due to their difference of capital structure. In addition, the researcher used profitability as measure of firm's financial performance while the future research can have ROA, ROE, and EPS etc as firm's financial performance.

Keywords: Firm's performance, Textile sector, Food sector

\section{Introduction}

The companies in Textile sector and also in Food sector represent a large number of non-financial industries in Pakistan. Their Performance can also influence the other sector's financial decision making process. The previous studies conducted on firm's performance indicates that a large number of factors affect significantly the firm's performance. David Durand (1952) presented different theories for starting the argument on firm's value. He was of the view that increasing leverage can increase firm's performance but he could not provide the operational justification to validate his point of view. The study conducted by Modigliani and Miller (1958) reveals that levered and unleveraged firm's can be made equal in value by applying the arbitrage process. Modigliani and Miller (1963) also found that debt provide the tax shield advantage in the form of interest. A lot of studies afterwards reveal that corporate financial performance or firm's performance influenced by a number of factors that should keep in mind while making financial decision to increase a firm's performance. The researcher used the framework of (Zeitun and Tian, 1997). They used leverage, growth, size, tax, risk and tangibility to see their effect on corporate performance of Jordan non-financial sector. The researcher extended the regression model by including liquidity and non-debt tax shield (depreciation) to make this study more comprehensive.

\subsection{Significance of the Study}

The companies in textile sector and in food sector cover a larger part of population of 
non-financial industry of Pakistan. Both of these sectors can influence the performance of other sectors by their financial decision making and actions thereof. By comparing their financial performance through profitability and identifying the factors affecting it, the researcher can explore the ways by which firm's performance can be groomed in overall non-financial sector of Pakistan.

\subsection{Objective of the Study}

The researcher's objective is to find out the different factors which are significantly affecting firm's performance in textile and food sector of Pakistan for the period 2005-2010.

\subsection{Research Questions}

The researcher wants to explore the current study with reference to the following researcher questions:

1. What factors are significantly impacting the firm's performance in textile industry of Pakistan?

2. What factors are significantly impacting the firm's performance in food industry of Pakistan?

\section{Literature Review}

A large number of previous studies relating to firm's performance or sometimes corporate performance has identified a number of factors that empirically and even significantly affecting the firm's performance. There are a little number of research findings available in Pakistani context relating to firm's performance however the foreign researchers has done a lot in this context. The researcher used the framework of Zeitun and Tian (2007) with the extension in their regression model by adding liquidity and non-debt tax shield and applied this regression model simultaneously on textile and food sectors of Pakistan. The findings of Zeitun and Tian (2007) indicated that leverage has a significant and negative relationship with firm's performance. They used leverage, growth, size, tax, risk and tangibility as independent variable to see their effect on firm's performance. They concluded that firm's size and tax have positive and significant relationship with firm's performance while risk and tangibility have negative and significant relationship with firm's performance. Memon, Bhutto and Abbas (2010) concluded in their study of capital structure and firm's performance on textile sector that the companies in this sector are performance below optimum level of capital structure and also fail to achieve the economies of scale. Nosa and Ose (2010) found that effective funding required for the growth and development of the corporations in Nigeria. They suggested enhancing the regulatory framework for increasing the firm's performance by focusing on risk management and corporate governance. Onaolapo and Kajola (2010) found a significant and negative relationship between debt ratio and firm's financial performance. The study conducted by Krishnan and Moyer (1997) found a negative and significant relationship between leverage and firm's performance while other factors affecting firm's performance positively includes size, growth, tax and risk. Jensen and Meckling (1976) found two types of agency cost; agency cost of equity holders and agency cost of debt holders. They concluded that a conflict of interest arises between the management and the shareholders when management take decision against 
the interest of shareholders and another conflict arises when the shareholder act against the interest of debt holders. William (1987) found that decision for high leverage by the management decreases the conflict between management and shareholders. The leverage can work as disciplinary device that controls the management from wasting their firm's resources according to (Grossman and Hart, 1982). The researcher in the current study used short term as well as long term debts as proxy for leverage and also the other factors like growth, size, tax, risk, tangibility, liquidity and non-debt tax shield for measuring their impact on firm's financial performance in textile as well as food sector comparatively for the period 2005-2010.

\section{Data and Methodology}

\subsection{Data and Source}

The type of data is panel/longitudinal and has been created from the State Bank of Pakistan's annual publication "Financial Statement Analysis of companies (non-financial) listed in Karachi Stock Exchange for the period 2005-2010". This statement contains the 6 years financial figures of 12 different sectors relating to non-financial industry having 411 firms in total and available online at www.sbp.org.pk while the researcher selected the 2 sectors like Textile and Food sector for comparison as both sector covers the greatest part of overall population of non-financial industry in Pakistan.

The sample consists of 139 companies from textile sector and 39 companies from food sector of Pakistan. The findings of the current study is applicable on all sectors of non-financial industry of Pakistan as the sample selected covers $44 \%$ approximately of the whole population of non-financial industry.

It is not applicable on financial industry like banks and insurance sector as their capital structure is entirely different from non-financial sector.

\subsection{Econometric Regression Model}

For regression analysis of Panel data, there are three methods available for their regression like fixed effect, Random effect and constant coefficient regression model. The choice between fixed effect and random effect is finalized by hausman specification test (1978) while the choice between random effect and constant coefficient model is finalized by Lagrange multiplier test. As there is a large number of companies in the current study while the time period is small so the data type is short panel according to (Baltagi, 2005). The researcher expects a cross sectional fixed effect with constant in the current study and developed the following regression model for the estimation of current study:

$$
\begin{aligned}
& (F P)_{i t}=\left(\beta_{0}+u_{i}\right)+\beta 1(L V)_{i t}+\beta 2(G R)_{i t}+\beta 3(S Z)_{i t}+\beta 4(R K)_{i t}+\beta 5(T X)_{i t}+\beta 6(T N)_{i t}+\beta 7(L Q)_{i t} \\
& +\beta 8(N D)_{i t}+V_{i t}
\end{aligned}
$$

\section{Where}

FP = Firm's Performance (ROI)

$\beta_{0}+u_{i}=$ Constant coefficient including cross sectional fixed effect

$\beta_{1}-\beta_{8}=$ Regression coefficients for measuring independent variables

$\mathrm{LV}=$ Leverage 
GR = Growth

$\mathrm{SZ}=$ Size

RK $=$ Risk

$\mathrm{TX}=\mathrm{Tax}$

$\mathrm{TN}=$ Tangibility

LQ = Liquidity

ND $=$ Non-debt Tax shield

$V_{i t}=$ Error component showing unobserved factor

\subsection{Variables and Hypothesis Development}

The previous studies have shown a number of proxies for measuring firm's financial performance like ROA, ROE, Tobin's Q, EPS and ROI. Some of these variable required current market data like Tobin's Q. The researcher in the current study used Return on asset (ROI) as dependent variable for measuring firm's financial performance while the independent variables includes short term and long term leverage, growth, firm's size, risk, tax, tangibility of fixed assets, liquidity and non-debt tax shield (depreciation).

The description of each variable and their expected signs are given below in the following table:

Table 1. Explanation of Dependent and Independent variables and Expected signs

\begin{tabular}{|l|l|c|}
\hline \multicolumn{3}{|c|}{ Dependent Variable } \\
\hline Return on assets & \multicolumn{2}{|c|}{ EBIT/Total Assets } \\
\hline \multicolumn{2}{|c|}{ Independent Variables } \\
\hline Variables Names & \multicolumn{1}{|c|}{ Description } & Expected Signs \\
\hline Leverage & Short term debt/Total assets, Long term debt/Total Assets & Negative \\
\hline Growth & $\Delta$ Total Assets/ Total Assets & Positive \\
\hline Size & Natural Log of Total Sales & Positive \\
\hline Risk & EBIT/Earning after interest and Tax & Positive \\
\hline Tax & Current year's Tax/Earnings before Tax & Positive \\
\hline Tangibility & Fixed Assets/Total Assets & Positive \\
\hline Liquidity & Current Assets/Current Liabilities & Positive \\
\hline NDTS & EBIT + Depreciation/Total Assets & Positive \\
\hline
\end{tabular}

On the basis of above table the relationships between dependent and independent variables have been developed in the following hypothesis:

$H_{1}$ : Leverage (short \& long term) should have a negative impact on firm's performance.

$\mathrm{H}_{2}$ : Growth should have a positive impact on firm's performance.

$H_{3}$ : Firm's size should have a positive impact on firm's performance.

$H_{4}$ : There should be a positive relationship between risk and firm's performance.

$H_{5}$ : There should be a positive relationship between tax and firm's performance 
$H_{6}$ : Tangibility should have a positive relationship with firm's performance.

$H_{7}$ : Liquidity should have a positive relationship with firm's performance.

$H_{8}$ : There is a positive relationship between Non-debt tax shield and firm's performance.

\section{Regression Analysis and Discussion on Findings}

The researcher used STATA 11 software for the regression analysis of the current study. The dependent variable is firm's performance measure ROI while the independent variables includes Leverage (short, long), Growth, Size, Risk, Tax, Tangibility, Liquidity and Non-debt tax shield. The combine descriptive statistics showing mean, standard deviation, minimum and maximum values of both textile and food sector are indicated in table 4.1 while correlation matrix of textile sector is indicated in table 4.2 (a) and of food sector is indicated in table 4.2 (b). The regression result of both sectors by using one-way fixed effect model is indicated in table 4.3. The presence of fixed cross sectional effect is evidenced by the significant results of hausman test which validate the name of this model as one way-fixed effect model according to (Baltagi, 2005).

Table 2. Descriptive Statistics

\begin{tabular}{|c|c|c|c|c|c|c|c|c|}
\hline \multirow[b]{2}{*}{ Variables } & \multicolumn{4}{|c|}{ Textile Sector } & \multicolumn{4}{|c|}{ Food Sector } \\
\hline & Mean & SD & Min & Max & Mean & SD & Min & Max \\
\hline FP & .0231793 & .1554565 & -1.71287 & 1.736175 & .0895812 & .2454644 & -1.9607 & 1.5366 \\
\hline S-LV & .5139861 & .2567038 & .0085605 & 2.546073 & .9987258 & 2.308849 & 0 & 21.0027 \\
\hline L-LV & .2236888 & .2091147 & 0 & 1.730722 & .3420604 & .956483 & 0 & 8.2593 \\
\hline GR & .0337597 & .2263425 & -2.86857 & .9645731 & .0545845 & .3791248 & -3.1423 & .869221 \\
\hline SZ & 13.88058 & 1.417079 & 7.34601 & 17.26663 & 14.2658 & 1.374033 & 9.43284 & 17.7569 \\
\hline RK & 1.388222 & 4.136975 & -42.9379 & 73.95914 & 1.143094 & 1.292506 & -3.4124 & 16.1192 \\
\hline $\mathrm{TX}$ & .8204285 & 13.75174 & -58.7819 & 381.2666 & .1621389 & .6174747 & -1.2676 & 6.9061 \\
\hline $\mathrm{TN}$ & .9245616 & .4761682 & 0 & 5.93239 & 1.018567 & .7769611 & 0 & 8.1421 \\
\hline LQ & 1.045564 & 1.070488 & .04 & 10.55 & .9958023 & .7317717 & 0 & 4.57 \\
\hline ND & .1021373 & .5978221 & -10.9418 & 5.070107 & .2598513 & .6398823 & -5.4244 & 3.5937 \\
\hline
\end{tabular}

The above table 2 indicates the descriptive statistics like Mean, Standard deviation, Min and Maximum of Firm's performance (ROI) and other firm's specific factors like Leverage, Growth, Size, Risk, Tax, Tangibility, Liquidity and Non-debt tax shield (Depreciation) during the period 2005-2010 for Textile and Food sector of Pakistan on comparative basis. The above table indicate that short term leverage has an average (mean) value as $51 \%$ in case of textile sector's firm's performance while in case of Food sector it has an average (mean) value of $100 \%$ approximately. It means that short term leverage contribute more in case of food sector. While long term leverage showing (mean) value as $22 \%$ in case of Textile sector while in case of Food sector it shows $34 \%$ which also states that long term leverage also plays an important role in the determination of firm's performance in food sector better than textile sector. The firm's Size in case of Textile sector on average (mean) value showing $139 \%$ while in case of food sector it has $142 \%$ approximately. It means that firms in food sectors are larger in size. 
The other factors can be analyzed with the same pattern of comparison between textile and food sector.

Table 2(a). Correlation Matrix for Textile Sector

\begin{tabular}{|l|c|c|c|c|c|c|c|c|c|c|}
\hline & FP & S-LV & L-LV & GR & SZ & RK & TX & TN & LQ & ND \\
\hline FP & 1.000 & & & & & & & & & \\
\hline S-LV & -0.056 & 1.000 & & & & & & & & \\
\hline L-LV & -0.132 & -0.079 & 1.000 & & & & & & & \\
\hline GR & 0.089 & -0.109 & -0.108 & 1.000 & & & & & & \\
\hline SZ & 0.137 & -0.194 & -0.129 & 0.223 & 1.000 & & & & & \\
\hline RK & 0.057 & 0.003 & -0.030 & 0.002 & 0.063 & 1.000 & & & & \\
\hline TX & -0.003 & 0.026 & -0.013 & -0.003 & -0.018 & -0.007 & 1.000 & & & \\
\hline TN & -0.106 & 0.264 & 0.262 & -0.277 & -0.413 & -0.041 & -0.000 & 1.000 & & \\
\hline LQ & 0.039 & -0.204 & -0.121 & -0.015 & 0.051 & 0.029 & -0.036 & -0.101 & 1.000 & \\
\hline ND & 0.705 & -0.044 & -0.092 & 0.060 & 0.053 & 0.017 & -0.609 & -0.045 & 0.045 & 1.000 \\
\hline
\end{tabular}

The above table 2(a) indicates the correlation matrix of dependent and independent variables in textile sector of Pakistan for the period 2005-2010. It indicates that short term and long term leverage including tax and tangibility having negative correlation with firm's performance while growth, size, risk, liquidity and non-debt tax shield having positive correlation with firm's performance in textile sector of Pakistan. The highest correlation is indicated between non-debt tax shield and firm's performance as 0.71 approximately according to the above table.

Table 2(b) Correlation Matrix for Food Sector

\begin{tabular}{|l|r|r|r|r|r|r|r|r|r|c|}
\hline & FP & S-LV & L-LV & GR & SZ & RK & TX & TN & LQ & ND \\
\hline FP & 1.000 & & & & & & & & & \\
\hline S-LV & -0.164 & 1.000 & & & & & & & & \\
\hline L-LV & -0.076 & 0.490 & 1.000 & & & & & & & \\
\hline GR & 0.265 & -0.088 & -0.010 & 1.000 & & & & & & \\
\hline SZ & 0.227 & -0.199 & -0.097 & 0.168 & 1.000 & & & & & \\
\hline RK & 0.042 & -0.012 & 0.004 & -0.023 & 0.003 & 1.000 & & & & \\
\hline TX & 0.076 & -0.016 & -0.023 & 0.072 & 0.084 & -0.004 & 1.000 & & & \\
\hline TN & -0.172 & 0.047 & 0.126 & -0.353 & -0.353 & -0.075 & -0.150 & 1.000 & & \\
\hline LQ & 0.243 & -0.125 & -0.147 & 0.200 & 0.237 & 0.006 & 0.113 & -0.286 & 1.000 & \\
\hline ND & 0.978 & -0.126 & -0.057 & 0.285 & 0.162 & 0.013 & 0.059 & -0.182 & 0.188 & 1.000 \\
\hline
\end{tabular}

The above table 2(b) shows correlation matrix between dependent and independent variable of food sector of Pakistan for the period 2005-2010. It shows that Leverage (both short and long term) and tangibility having negative correlation with firm's performance while growth, size, risk, tax, liquidity and non-debt tax shield (depreciation) having positive correlation with firm's performance. The above table also indicates the highest correlation between non-debt tax shield and firm's performance as 0.98 . 
Table 3. Regression Results-One way fixed effect regression model

Dependent Variable $=$ Firm's Performance $(\mathrm{ROI})$

\begin{tabular}{|c|c|c|c|c|c|c|c|c|}
\hline \multirow{3}{*}{$\begin{array}{c}\text { Independent } \\
\text { Variables }\end{array}$} & \multicolumn{4}{|c|}{ Textile Sector } & \multicolumn{4}{|c|}{ Food Sector } \\
\hline & \multicolumn{2}{|c|}{$1^{s t}$ Model $\left(\beta_{1}=S-L V\right)$} & \multicolumn{2}{|c|}{$2^{\text {nd }}$ Model $\left(\beta_{I}=L-L V\right)$} & \multicolumn{2}{|c|}{$1^{s t}$ Model $\left(\beta_{1}=S-L V\right)$} & \multicolumn{2}{|c|}{$2^{\text {nd }}$ Model $\left(\beta_{1}=L-L V\right)$} \\
\hline & $\begin{array}{c}\text { Coefficient } \\
\text { s }\end{array}$ & $\begin{array}{c}\text { P-value } \\
\text { s }\end{array}$ & $\begin{array}{c}\text { Coefficient } \\
\text { s }\end{array}$ & $\begin{array}{c}\text { P-value } \\
\text { s }\end{array}$ & $\begin{array}{c}\text { Coefficient } \\
\text { s }\end{array}$ & $\begin{array}{c}\text { P-value } \\
\text { s }\end{array}$ & $\begin{array}{c}\text { Coefficient } \\
\text { s }\end{array}$ & $\begin{array}{c}\text { P-value } \\
\text { s }\end{array}$ \\
\hline S/L-LV & -.031593 & $* * 0.026$ & .0198823 & 0.221 & -.002251 & 0.419 & .009118 & $* * 0.034$ \\
\hline GR & -0.014184 & 0.239 & -.0124429 & 0.302 & -.002579 & 0.751 & -.002312 & 0.773 \\
\hline SZ & .018694 & $* 0.000$ & .0188960 & $* 0.000$ & .033499 & $* 0.000$ & .032001 & $* 0.000$ \\
\hline RK & .001423 & $* * 0.023$ & .0014425 & $* * 0.021$ & .005855 & $* 0.006$ & .005740 & $* 0.006$ \\
\hline $\mathrm{TX}$ & .007753 & $* 0.000$ & .0077907 & $* 0.000$ & .000260 & 0.956 & -.000437 & 0.925 \\
\hline $\mathrm{TN}$ & -.007214 & 0.511 & -.0116991 & 0.298 & .029579 & $* 0.000$ & .029295 & $* 0.000$ \\
\hline LQ & -.000747 & 0.843 & -.0002636 & 0.944 & .003988 & 0.551 & .002653 & 0.687 \\
\hline ND & .294883 & $* 0.000$ & .2966095 & $* 0.000$ & .363463 & $* 0.000$ & .365022 & $* 0.000$ \\
\hline $\mathrm{C}$ & -.250596 & 0.001 & -.2707327 & 0.000 & -.521193 & 0.000 & -.503767 & 0.000 \\
\hline Observations & & $=834$ & & $=834$ & & $=234$ & & $=234$ \\
\hline No of Groups & & $=139$ & & $=139$ & & $=39$ & & $=39$ \\
\hline \multirow{2}{*}{$\begin{array}{l}\text { Overall Model } \\
\text { Fitness }\end{array}$} & \multicolumn{2}{|c|}{$F(8,687)=325.51$} & \multicolumn{2}{|c|}{$F(8,687)=323.44$} & \multicolumn{2}{|c|}{$F(8,187)=910.53$} & \multicolumn{2}{|c|}{$\mathrm{F}(8,187)=929.99$} \\
\hline & \multicolumn{2}{|c|}{ Prob $>F=0.0000$} & \multicolumn{2}{|c|}{ Prob $>F=0.0000$} & \multicolumn{2}{|c|}{ Prob $>F=0.0000$} & \multicolumn{2}{|c|}{ Prob $>F=0.0000$} \\
\hline R2 (Within) & \multicolumn{2}{|c|}{$=0.7913$} & \multicolumn{2}{|c|}{$=0.7902$} & \multicolumn{2}{|c|}{$=0.9750$} & \multicolumn{2}{|c|}{$=0.9755$} \\
\hline R2 (Between) & \multicolumn{2}{|r|}{$=0.7833$} & \multicolumn{2}{|r|}{$=0.7926$} & \multicolumn{2}{|r|}{$=0.8827$} & \multicolumn{2}{|r|}{$=0.8752$} \\
\hline R2 (Overall) & \multicolumn{2}{|r|}{$=0.7847$} & \multicolumn{2}{|c|}{$=0.7866$} & \multicolumn{2}{|r|}{$=0.9533$} & \multicolumn{2}{|r|}{$=0.9521$} \\
\hline \multirow{2}{*}{$\begin{array}{l}\text { F-test that all } \\
\mathrm{u}-\mathrm{i}=0\end{array}$} & \multicolumn{2}{|c|}{$F(138,687)=1.57$} & \multicolumn{2}{|c|}{$F(138,687)=1.54$} & \multicolumn{2}{|c|}{$\mathrm{F}(38,187)=3.65$} & $\mathrm{~F}(38$, & $87)=3.94$ \\
\hline & Prob> & $\mathrm{F}=0.0001$ & Prob> & $\mathrm{F}=0.0003$ & Prob> & $\mathrm{F}=0.0000$ & Prob> & $\mathrm{F}=0.0000$ \\
\hline Hausman test & Prob $>\mathrm{C}$ & $\mathrm{ni} 2=0.000$ & Prob $>C$ & $\mathrm{ni} 2=0.007$ & Prob $>\mathrm{Ch}$ & $2=0.0427$ & Prob $>C h$ & $2=0.0000$ \\
\hline & Note: The & urrent table & is generated & $y$ the outp & STATA 11 & egression $r$ & & \\
\hline & *significan & at $1 \%$ leve & 1, **significan & $\mathrm{t}$ at $5 \% \mathrm{lev}$ & $1, * * *$ signific & nt at $10 \%$ & & \\
\hline $\mathrm{S}-\mathrm{LV}=\mathrm{Shc}$ & $\begin{array}{r}\text { term leverag } \\
\mathrm{TN}=\mathrm{Ta}\end{array}$ & $\begin{array}{l}\text { L-LV }=\mathrm{Lo} \\
\text { ngibility, } \mathrm{L}\end{array}$ & $\begin{array}{l}\text { ng term Lever } \\
\mathrm{Q}=\text { Liquidity, }\end{array}$ & $\begin{array}{l}\text { age, } G R=G \\
\text { JD=Non-de }\end{array}$ & $\begin{array}{l}\text { rowth, } \mathrm{SZ}=\text { Fir } \\
\text { bt Tax shield, }\end{array}$ & $\begin{array}{l}\text { m's Size, } \\
C=\text { Constar }\end{array}$ & $\mathrm{K}=$ Risk, $\mathrm{TX}=$ & Tax, \\
\hline
\end{tabular}

The above table 3 indicates results of one-ways fixed effect regression model estimation. The overall model is statistically fit and significant in both sectors. It indicates that short term leverage is significant at $5 \%$ level in textile sector and long term leverage is significant at $5 \%$ level in food sector both showing negative relationship with firm's performance and accepts the $1^{\text {st }}$ hypothesis. The negative relation between leverage and firm's performance is also consistent with the following researchers like (Krisnan and Moyer, 1997; Zeitun and Tian, 2007; Onaolapo and kajola, 2010; Memon, Bhutto and Abbas, 2010). It indicates that firm's performance in textile sector is significantly influenced by short term debts and in food sector by long term debts. Growth is not significant at any level in both sector and showing negative relationship which rejects the $2^{\text {nd }}$ hypothesis. However the negative relationship between growth and firm's performance is consistent with the similar findings of previous researchers (Zeitun and Tian, 2007). While the other researchers found positive relationship between firm's 
performance and growth like (Krishnan and Moyer, 1997; Onaolapo and Kajola, 2010; Memon, Bhutto and Abbas, 2010). Firm's size is significant @ $1 \%$ level both in textile and food sector and accepts the $3^{\text {rd }}$ hypothesis. This positive relationship is consistent with the following researchers like (Krishnan and Moyer 1997; Zeitun and Tian, 2007; Onaolapo and Kajola, 2010). It indicates that firm's size increases firm's performance in both textile and food sector of Pakistan. Risk is significant at 5\% level in textile sector while it is significant at $1 \%$ level in food sector. In both sector it is showing positive relationship which accepts $4^{\text {th }}$ hypothesis. This positive relationship between risk and firm's performance is also consistent with the previous researchers who found the same relationship like (Krishnan and Moyer, 1997; Memon, Bhutto and Abbas, 2010). It indicates that more risky firms tend to perform well in textile and food sector of Pakistan. Tax is significant at $1 \%$ level in textile sector and accepts $5^{\text {th }}$ hypothesis it is also consistent with the similar findings by (Krishnan and Moyer, 1997; Zeitun and Tian, 2007; Memon, Bhutto and Abbas, 2010). However the tax is not significant in food sector. It means that firm's performance in textile sector is influenced significantly in textile sector but not in food sector. Tangibility is not significant at any level in textile sector but it is significant at $1 \%$ level in food sector with positive relationship and accepts $6^{\text {th }}$ hypothesis. This finding of food sector is also consistent with the previous researcher with similar finding like (Nosa and Ose, 2010). It means that tangibility does not play a significant role for firm's performance in textile sector and having a significant and positive role for firm's performance in food sector which indicates that the performance of food sector is increased by tangibility. More tangible firms in food sector are performing well. Liquidity is not significant at any level in both sectors. It has negative relationship with firm's performance in textile sector that rejects the $7^{\text {th }}$ hypothesis but in food sector it shows positive and insignificant relationship with firm's performance which accepts the $7^{\text {th }}$ hypothesis. The non-debt-tax shield (depreciation) is significant at $1 \%$ level in both sectors and with positive relationship and accepts $8^{\text {th }}$ hypothesis. It means that non-debt tax shield plays an important and significant role for increasing firm's performance in both sectors.

\section{Conclusion and Recommendations}

The researchers used the one-way fixed effect regression model as suggested by Baltagi (2005) to identify empirically the significant factors affecting firm's performance in Textile and Food sector of Pakistan. The current study concluded that firm's performance in textile sector of Pakistan is significantly affected by Short term leverage, size, risk, tax and non-debt tax shield. It is recommended to the textile sector that they should make their financial decision by considering the above said factors regarding firm performance in this sector. It is also concluded that long term leverage, size, risk, tangibility and non-debt tax shield are the important and significant determinants of firm's performance in food sector of Pakistan. The companies in food sector of Pakistan are recommended to consider the above said factor while making financial decision regarding firm's performance in this sector.

\section{Policy Implications}

The results of the current study implies that the textile sector has to direct their policies towards firm's size, risk, tax and non-debt tax shield for increasing their firm performance while short 
term leverage decreases their performance. The study also implies that the food sector has to direct their policies towards long term leverage, firm's size, risk, tangibility of fixed assets and non-debt tax shield in order to increase firm's performance. All the above factors have a significant impact on firm's performance in their respective sector like textile and food.

\section{Limitations and Suggestions}

The current study is limited and applicable to non-financial industry of Pakistan only. It is not applicable to financial sector as their capital structure is entirely different from non-financial sector. The researcher used book value measure for dependent and independent variables. The future research on firm's performance may be made through market value measures like Tobin's Q etc. The future research may also be conducted on financial sector using the same models and variables.

\section{References}

Baltagi, B. H. (2005). "Econometric analysis of panel data, $3{ }^{\text {rd }}$ edition", John wiley and sons ltd.

Campbell, A. (2007). "Introduction to Econometrics", MIT. "Financial statement analysis of Non-financial companies listed in Karachi Stock Exchange for the period 2005-2010", Statistic and DWH department, State Bank of Pakistan.

Jensen, \& Meckling. (1986). Agency cost of Free Cash Flows, Corporate Finance and Takeovers. American Economic Review, 76, 323-329.

Krishnan, \& Moyer (1997). Performance, Capital Structure and Home Country: An analysis of Asian Countries. Global Finance Journal, 8(1), 129-143. http://dx.doi.org/10.1016/S1044-0283(97)90010-7

Memon, Bhutto, \& Abbas. (2010). Capital Structure and firm's performance: A case of Textile sector of Pakistan. Asian Journal of Business and Management Science, 9(1), 9-15.

Nosa, \& Ose. (2010). Capital Structure and Corporate Performance in Nigeria: An empirical investigation. Journal Of Management Sciences, 1(1), 43-52.

Onaolapo, \& Kajola. (2010). Capital structure and Firm's Performance: Evidence from Nigeria. European Journal of Economics, Finance and Administration Sciences, 25, 70-82.

Park. (2009). Linear regression models for panel data using SAS, STATA, LIMDEP and SPSS. Indiana University.

Pratheepkanth, P., (2011). Capital Structure and Financial performance: Evidence from Selected Business Business Companies from Colombo Stock Exchange Srilanka. International Referred Research Journal, 2(2), 171-183.

Wooldridge, J. M., Introductory Econometrics: A modern Approach. $2^{\text {nd }}$ Edition.

Zeitun, R., (2009). Ownership Structure, Corporate Performance and Failure: Evidence of Panel Data of emerging market, a case of Jordon, Corporate Ownership and Control, 6(4), 
96-114.

Zeitun, R., \& Tian, G. G., (2007). Capital Strucutre and Corporate performance: Evidence from Jordon. Australasian Accounting, Business and Finance Journal, 4(1), article 3.

\section{Copyright Disclaimer}

Copyright reserved by the author(s).

This article is an open-access article distributed under the terms and conditions of the Creative Commons Attribution license (http://creativecommons.org/licenses/by/3.0/). 